LISA HAINES is Vice President of Public Affairs for Disneyland Resort and graduated with a degree in Political Science in 1989 from Cal Poly. 


\section{ALUMNI SPOTLIGHT}

Lisa Haines Heppelmann

"Do the best job possible and you will be recognized," was the advice Lisa Haines Heppelmann offered to students and graduates alike. This mantra rings true when looking at Lisa's career path.

While attending Cal Poly she interned for her local congressperson, once in his district, and then again in Washington D.C. Looking back she noted that it was her summer internships that gave her a pathway to a career after graduation.

After she graduated, Lisa started her first job; she worked on her Congressman's re-election campaign. She did anything and everything, from making copies to meeting with the political consulting/public relations firm helping with the campaign. One meeting in particular stood out to Lisa; she was waiting inside to meet the representative from the firm, and it was raining heavily outside. Lisa saw the representative get out of his car and fidget around for an umbrella. He did not have one, but Lisa did. She ran outside to meet him and walked him into the building under her umbrella. After six months of active campaigning, the Congressman left the race because of personal matters. Lisa, who was fresh out of college working her first job, and was now left unemployed, received a phone call from the political consultant she had met 
with on that rainy day. He offered her a temporary job working through the campaign season, and that temporary job turned into a six-year stint working in PR and political consulting.

After many campaign cycles, Lisa was ready for something new. She wanted to venture into the public relations field a bit more. A few months of searching for a job led her to a healthcare company where she started as Manager of Public Relations. Lisa worked for this company for the next eight years in several different capacities, coming to fruition when she did all of the merger communications when another healthcare company was acquiring her company. Her work got the attention of the acquiring company, and they kept her on in a director role. She spent the next five years doing corporate communication and thoroughly enjoyed her position, colleagues, and the company. Amusingly enough, at this point her in life, she was not looking for a change in her career path, but it happened anyway.

Lisa met a woman at a barbeque who was forming a public affairs team at the corporate level for Walt Disney Parks and Resorts, one of the four main segments of The Walt Disney Company. They talked throughout the barbeque, and she asked Lisa if she was interested in a possible position. Originally, Lisa said no. She was very happy with her current job. On her drive home from the barbeque, she realized that this had the potential to be a great opportunity. Lisa interviewed for the position, and a few months later began working for Disney. She started as Vice President of External Communications, which allowed her the opportunity to work on the opening of the Disney park in Hong Kong. After nearly five years in that role, Lisa moved to the Disneyland Resort to serve as Vice President of Communications, where she was responsible for all internal and external communications. This led to the position Lisa now holds as Vice President of Public Affairs for the Disneyland Resort. In this role, Lisa oversees a team of 60 Cast Members whose responsibilities include internal and external communications, government and community relations, and executive engagement. Wearing many different hats, Lisa thrives on the fact that day-today occurrences are never the same. Her adaptability and ability to be flexible are constantly being tested. While she explained that the unpredictability could be difficult, she loves working for a large well-known brand. Whenever she has a tough day, Lisa will walk through the Disneyland park and be reminded that what she does as a part of Disney brings happiness to so many. 
As a professional with many years in the workforce, Lisa offers some helpful advice to students and young professionals: "Make your time mean something." Lisa was adamant about making the most of summer breaks and the importance of gaining experience through work or internships. Without her summer internships, Lisa said she would not know where she would be today. As someone who reviews a lot of resumes in her current role, she firmly believes this hands-on experience really sets applicants apart in the job market. In addition, Lisa reminded students not to underestimate the importance of informational interviews. Even if there is no spot available at that time, an employer will remember the impression you made on them when you sat face to face. Lisa "blindly found" her path, but that would not have happened without the effort and time she put into her internships and the jobs that followed. She encourages students to focus on having a strong work ethic and doing great work, and their talents will be noticed. 